\title{
A TRIPULAÇÃO DE ODISSEU E O PROÊMIO DA ODISSELA
}

\author{
Gustavo Henrique Montes Frade` \\ Universidade Federal de Minas Gerais
}

\begin{abstract}
This work relates the presence of Odysseus' crew and of the eating of the cattle of Helios in the first verses of the Odyssey to three narrative functions of the proem: a first definition of Odysseus and his poem; the setting of a starting point to the narrative selection; and an introduction to the Odyssean themes of human error caused by ignoring warnings and the relations between gods and humans, two themes explicitly connected in Zeus' speech (I, 32-43). The companions are the first example of failure caused by a bad reading of the world, which leads them to the foolish decision of committing an impiety. They are also the first examples of the extreme consequences of a god's rage.
\end{abstract}

KEYWORDS: Homer; Odyssey; proem; companions; narrative.

m geral, o narrador da Odisseia utiliza a apresentação de informações que compõem um contexto, a descrição de ações e o diálogo de modo que seus personagens tenham primeiras aparições em cena significativas. Elas já revelam para os receptores (audiência ou leitores) as características importantes ou mesmo essenciais desses personagens, como amostra do que será sequencialmente aprofundado na narrativa. ${ }^{1}$ Em alguns casos, mesmo a primeira menção ao personagem condensa algo desses elementos. A tripulação de Odisseu é mencionada logo no início do poema, nos primeiros dez versos, que aqui serão chamados de "proêmio" (I, 1-10):

\footnotetext{
^ghmfrade@gmail.com

${ }^{1}$ Cf. Race, 1993, p. 79.
} 
Homem multiversátil, Musa, canta, que tanto vagueou, depois que de Troia destruiu a cidadela sagrada. Muitos foram os povos cujas cidades observou, cujos espíritos conheceu; e foram muitos no mar os sofrimentos por que passou para salvar a vida, para conseguir o retorno dos companheiros a suas casas.

Mas eles, embora o quisesse, não logrou salvar.

Não, pereceram devido à sua insensatez,

pueris, que devoraram o gado sagrado de Hipérion, o Sol - e assim lhes negou o deus o dia do retorno.

Começando de algum ponto fala-nos agora, ó deusa, filha de Zeus. ${ }^{2}$

Alguns comentadores que se propõem a compreender a menção à tripulação e ao episódio das vacas do Sol no proêmio partem da perplexidade de Stephanie West diante das seguintes questões problemáticas: o proêmio só contempla eventos cuja narração representa um terço do poema, apresenta uma escolha estranha de detalhes e dá ênfase desproporcional a um único incidente, sendo que as ações condenáveis dos pretendentes seriam muito mais importantes no poema do que a dos tripulantes. Diante disso, West propõe uma conclusão que segue uma linhagem analista. Esses seriam os versos introdutórios compostos para outro poema, outra Odisseia que teria conteúdo e organização narrativa que correspondesse exatamente ao que é neles apresentado. ${ }^{3}$ Esses problemas são resolvidos, ou ao menos amenizados, se considerarmos que o proêmio tem basicamente três funções na unidade narrativa que compõe a obra: definir Odisseu e a Odisseia (ou esboçar uma definição primeira do herói e do poema), estabelecer o ponto de início de seu recorte narrativo dentro da tradição mítica e introduzir temas importantes para o poema, tratados de forma explícita e relacionada pouco depois, no discurso de Zeus (I, 32-43), o erro cometido por ignorar avisos prévios e a relação entre deuses e homens. Por caminhos diversos, as três funções acabam convergindo para a questão da presença dos tripulantes no proêmio. Como um primeiro grupo de insensatos que se opõem a Odisseu, estes funcionam também como o primeiro passo na

\footnotetext{
${ }^{2}$ Os versos da Odisseia são citados com a tradução de Frederico Lourenço (cf. Homero, 2011) como base, com eventuais alterações indicadas por itálico. Neste caso específico, o texto em itálico corresponde a uma adaptação feita a partir da tradução de Trajano Vieira (cf. Homero, 2012). Lourenço traduz os dez primeiros versos gregos em onze versos em português.

${ }^{3}$ Cf. Heubeck, West, Hainsworth, 1988, p. 68-69. Cf. Rijksbaron, 1993; Walsh, 1995 e Cook, 1995.
} 
preparação para a introdução dos pretendentes, os principais adversários em Ítaca, na narrativa.

Algo das três funções do proêmio já era percebido por Bassett. Ele via no proêmio da Odisseia, e também no da Ilíada, a referência direta às vastas possibilidades do tema (nas palavras $\mu \alpha \dot{\alpha} \lambda \alpha, \pi \mathrm{o} \lambda \lambda \dot{\alpha}, \pi \mathrm{o} \lambda \lambda \tilde{\omega} \nu$, $\pi \mathrm{o} \lambda \lambda \alpha$, com significado de "muito" ou "muitos" nos primeiros quatro versos) que caracteriza a épica. ${ }^{4}$ No verso $10, \alpha \mu$ ó $\theta \varepsilon v$ (“de algum lugar”) introduz a armação narrativa dos quarenta dias em que se passa a ação do poema, depois da apresentação do herói em contraste com sua tripulação. Os três pontos básicos do proêmio estão aí parcialmente observados, mas é possível ser mais preciso a respeito de cada um deles.

Em seu texto originalmente publicado em 1946, Van Groningen compara os proêmios de poemas arcaicos aos quais temos acesso e identifica uma estrutura básica, composta por uma invocação das Musas (reconhecidas de forma geral entre os gregos como patronas da poesia) e pela indicação do assunto (o que garante a unidade narrativa e a coesão dentro da continuidade indefinida das histórias míticas, mas nunca corresponde a um sumário de todo o conteúdo narrativo dos poemas) e do ponto de início. O pesquisador sugere que a referência à morte da tripulação no proêmio é resultado de um processo de livre associação de ideias, que parte da aventura geral de tentar salvar a si mesmo e os companheiros para um caso particular. ${ }^{5} \mathrm{O}$ estabelecimento de um marco inicial, terceiro elemento da estrutura básica, se aproxima mais de uma explicação aceitável para essa menção da morte dos tripulantes logo no proêmio. Ele acerta, contudo, quando percebe que a primeira palavra de cada epopeia arcaica é o resumo mais conciso possível do poema: "cólera" na Ilíada, "homem" na Odisseia, "Ílion" (outra palavra para se referir a Troia) na Pequena Ilíada e "Argos" na Tebaida.

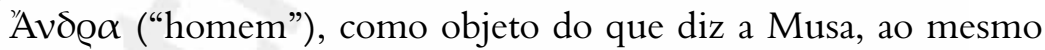
tempo inicia e condensa o esboço da definição de Odisseu e do poema. Esse início traz à mente as observações de Fenik sobre o tema do mistério da identidade que se manifesta no padrão do atraso da identificação definitiva do herói em cada ocasião em que ele se apresenta a outros

\footnotetext{
${ }^{4}$ Cf. Bassett, 1923, p. 341-345. Além do tema comum do sofrimento, ele observa também o paralelismo na organização das orações e a omissão de pontos importantes: a Ilíada não menciona que a história se passa em Troia, a Odisseia não menciona que o homem anunciado no primeiro verso é Odisseu.

${ }^{5}$ Cf. Van Groningen, 1999, p. 109-115.
} 
personagens. ${ }^{6}$ Para Kahane, entretanto, nesse caso não há ambiguidade sobre a identidade do herói, embora o homem do primeiro verso só receba um nome próprio no verso 21 e embora a palavra não seja de uso especial, podendo se referir a qualquer homem, ao contrário de $\mu \tilde{\eta} v ı \varsigma$, a primeira palavra da Ilíada que indica apenas a ira de Aquiles ou de um deus. ${ }^{7}$ Se ele levasse em consideração um receptor que tem seu primeiro contato com o poema, seja um ouvinte antigo que escuta pela primeira vez ou um leitor contemporâneo em sua primeira leitura, nesse caso — dependendo do conhecimento desse receptor a respeito da tradição poética ou mitológica ou do fato de ele estar informado de que a Odisseia é o poema de Odisseu - a confirmação plena sobre quem é esse herói só existe com a apresentação do nome. Kahane reconhece também, a partir de Goldhill, que a primeira palavra anuncia Odisseu como a representação modelo do homem em sociedade. ${ }^{8}$ Mas Odisseu, que de fato aparece como o exemplo de excelência, não se restringe a representar o que se espera de um homem no que diz respeito às relações sociais. No início do poema, pelo contrário, ele é exatamente alguém isolado da convivência humana. Os sentidos de ăvঠ@ $\alpha$ são desdobrados por Malta: como substituto do nome, se refere ao desaparecimento de Odisseu (e a seu posterior anonimato), ao homem adulto (modelo de seu papel social), à condição mortal e à condição humana geral. ${ }^{9}$

\footnotetext{
${ }^{6}$ Cf. Fenik, 1974, p. 20. O padrão se repete como preparação para o atraso mais importante e elaborado, a revelação da identidade de Odisseu para Penélope. Para Pedrick (1992, p. 45-47), o modo tradicional de abertura de proêmios, com uma identificação precisa do objeto, não serve para a Odisseia porque não se adequa à complexa identidade do herói, inextricavelmente relacionada ao tema da narrativa. ${ }^{7}$ Cf. Kahane, 1992, p. 117-119.

${ }^{8}$ Cf. Kahane, 1992; Goldhill, 1991. A proposta de Kahane (1992, p. 119) de que toda vez que ă $\alpha \delta \varrho \alpha$ aparece em posição inicial de verso na Odisseia há uma referência ao "homem objeto deste canto" parece não ser uma necessidade, mas algo sustentável apenas porque a ideia de Odisseu como modelo de excelência nas funções de prestígio para um homem em sociedade (guerreiro, marido e astucioso articulador de ardis) o torna identificável nas falas de Nestor, Telêmaco e Nausícaa. Entretanto, a ocorrência no canto XIII (89-91) apresenta mais similaridades estruturais com o proêmio e pode sim funcionar como uma marca divisória entre uma primeira parte que contém as viagens pelo mar e uma segunda parte com a retomada de Ítaca (cf. Clay, 1997, p. 190).

${ }^{9}$ Cf. Malta, 2007, p. 65-66. Mesmo o sentido de "guerreiro" como função do homem não estaria totalmente excluído, com o detalhe de que o proêmio classificará Odisseu como o tipo de herói da inteligência, em contraposição ao
} 
Odisseu, o humano por excelência, se define por ser capaz de recusar a imortalidade em troca de uma permanência limitada no mundo dos mortais e da imortalidade de seu nome nos versos cantados pelas pessoas que ainda viverão. Submeter-se a situações extremas, às restrições e incertezas que significam viver como um humano vale, para Odisseu, a recuperação de seu lugar — um lugar de honra — na humanidade. Ele precisa enfrentar os perigos de um espaço além dos limites do mundo humano e de suas expectativas, mas sua sobrevivência é resultado de uma excelência essencialmente humana. O sofrimento como integrante da caracterização essencial do personagem principal da narrativa (verso 4) faz parte aqui de uma visão sobre a existência mortal que se revela positiva, em que a ação apropriada permite a superação de ameaças à vida e ao retorno, ainda que não se passe incólume. Isso tudo é antecipado no próprio proêmio.

Ainda sobre a definição de Odisseu e da Odisseia, Pucci refina a abordagem intertextual e identifica no proêmio uma espécie de poética implícita com a defesa da Odisseia e do tipo de herói que é Odisseu diante de Aquiles e da Ilíada. O herói iliádico que causa a destruição de seu exército e opta pela morte é substituído pelo herói que tenta salvar seus companheiros e consegue preservar sua vida. ${ }^{10}$ A palavra que qualifica o homem cantado pela Musa, que funciona como uma primeira tentativa de identificação mais específica e também como condensação

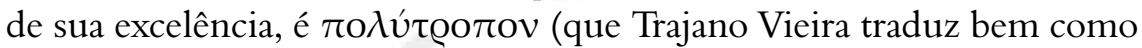
"multiversátil"), ${ }^{11}$ adjetivo atribuído na poesia grega arcaica só a Odisseu (I, 1 e X, 330) e a Hermes (Hino Homérico 4, verso 13), deus associado a Autólico, avô materno do herói. ${ }^{12}$ Literalmente, formado por $\pi \mathrm{o} \lambda u ́-$,

herói iliádico da força, embora o primeiro não deixe de ser também um guerreiro. Talvez Steinrück (2008), que lê a Odisseia sob a perspectiva do conflito jâmbico

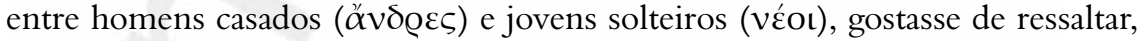
entre as atribuições de modelo social, a posição de marido.

${ }^{10}$ Cf. Pucci, 1998, p. 11-29.

${ }^{11}$ Cf. Homero, 2012.

${ }^{12} \mathrm{Na}$ Odisseia, Hermes o acompanhava e, como contrapartida a sacrifícios, lhe concedera o dom de superar a todos em furtos e perjúrios (XIX, 395-398). Há um fragmento de Hesíodo (fr. 64) em que ele aparece como filho do deus. É Autólico

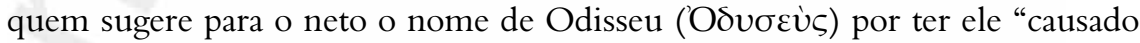

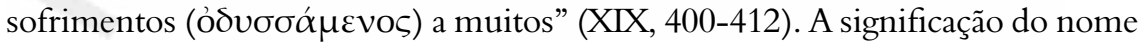
e o que ele diz sobre o personagem são questões antigas, revistas por Peradotto (1990, p. 94-119), sobretudo, quanto à possibilidade de um sentido ativo (o que 


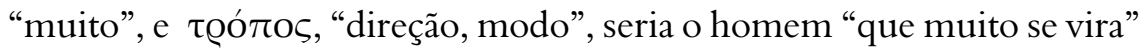
ou "de muitas voltas". Para Pucci, essa multiplicidade e essa versatilidade de Odisseu se aplicam a sua capacidade mental e sabedoria (afinal, é o herói

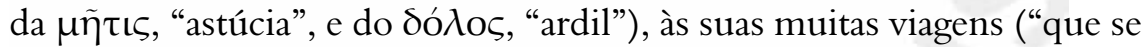
voltou para muitas direções”) e a sua habilidade com a linguagem. Isso é ao mesmo tempo o resultado de seu retorno peculiar e o que faz dele o personagem apto a completá-lo com sucesso. Peradotto lê $\pi 0 \lambda u ́ \tau \varrho o \pi o v$, que ocupa uma posição em que tradicionalmente se esperaria o nome do herói, como o contrário de um nome, uma palavra que, em vez de fixar um referente, indica a multiplicidade de sua forma, sua mutabilidade e capacidade de assumir papéis variados. ${ }^{13}$ Essa indefinição é, na verdade, parte da definição do herói - ou mesmo a maneira mais adequada de defini-lo - e corresponde a um modelo de excelência particular do poema (que será ampliado na sequência do proêmio e no primeiro discurso de Zeus): uma versatilidade que inclui inteligência, experiência e lábia para lidar com o que quer que apareça pela frente. ${ }^{14}$

É contra esse homem que se colocam os diversos adversários de Odisseu, ora com projetos diretamente opostos a seu objetivo de retorno e de retomada de sua posição em Ítaca, como os pretendentes, ora com desavenças causadas por desconfianças, como a sua tripulação. Esses dois grupos, por serem também formados por homens, precisam lidar com os problemas e incertezas característicos de sua condição comum

odeia) ou passivo (o que é odiado). Peradotto prefere um sentido ambíguo que se relaciona com o passivo e o ativo (que ele identifica como o sentido da voz média do grego antigo). Em relação a essa dupla relação entre ativo e passivo, Dimock (1956, p. 52-54) propõe algo na mesma direção, mas com um foco semântico um pouco diferente, sugerido "pelos propósitos poéticos da Odisseia": o sofrimento (ódúvๆ) que Odisseu proporciona aos outros e experimenta, como elemento essencial de sua identidade e humanidade. Essa caracterização de Odisseu aparece a partir do segundo verso do poema. Essas são as relações criadas para o nome no poema. Uma explicação etimológica é dada por Palmer (apud Peradotto, 1990, p. 164-165): prefixo verbal o- ("para”) + raiz do presente ( ${ }^{\star}$ deuk, indo-europeia, que dá o latim duco, "guiar") + sufixo -eus, formando o-dkj-eus, "o que conduz adiante", análogo ao sentido do nome de seu pai, conforme a etimologia de Palmer para Laertes: ^Lawo-er-ta, "o que incita o povo".

${ }^{13}$ Cf. Peradotto, 1990, p. 115.

${ }^{14}$ Esse aspecto próprio da excelência odisseica aparece em contraposição à força bruta de um herói como Aquiles, mas não substitui o conjunto de valores iliádicos da aristocracia guerreira, entre os quais sobressai a coragem, antes entra como um acréscimo que destaca Odisseu dentro dessa excelência aristocrática. 
conforme suas capacidades e possibilidades. Nunca agem, porém, com a "multiversatilidade" do herói. A menção aos tripulantes no proêmio encerra essa inicial caracterização de Odisseu com sua contraposição aos tripulantes que fracassam por um ato insensato.

A morte da tripulação é o elo selecionado para estabelecer o início da narrativa. Como explicita Walsh, em todos os relatos do poema, o caso da ilha Trinácia, em que os companheiros comem as vacas do Sol e são mortos por isso, é a última etapa antes da chegada de Odisseu a Ogígia, a ilha de Calipso. ${ }^{15} \mathrm{O}$ caso inaugura a fase da viagem sem companhia humana, que será reiniciada no canto $\mathrm{V}$ após um hiato de sete anos. Rijksbaron acrescenta que o narrador propõe que a Musa escolha seu ponto de partida ( $\alpha \mu o ́ \theta \varepsilon v$, "a partir de algum lugar”), mas com um limite já estabelecido. ${ }^{16}$ O proêmio não se propõe a dar um resumo das viagens e nem seleciona apenas uma aventura especialmente representativa do todo como exemplo. A sobrevivência de Odisseu à morte da tripulação explica e define sua situação inicial na narrativa, como único homem na ilha da ninfa. A escolha de começar a acompanhar Odisseu pouco antes de deixar Calipso permite a utilização de recursos narrativos importantes, como atrasar o aparecimento do herói em cena, acompanhar a viagem de Telêmaco em busca de informações (e seu retorno, em que se encontra com o pai antes do reconhecimento da mãe) e apresentar o relato das aventuras narrado em primeira pessoa pelo próprio herói. ${ }^{17}$

\footnotetext{
${ }^{15}$ Cf. Walsh, 1995.

${ }^{16}$ Cf. Rijksbaron, 1993. Segundo Pedrick (1982, p. 42-57), o narrador estabelece como limite começar depois da queda de Troia e antes do sacrifício das vacas do Sol, mas a Musa o corrige quanto ao ponto de partida e substitui o assunto da fúria do Sol pela de Posseidon e a oposição dos tripulantes pela dos pretendentes. A leitura de Walsh (1995) tem a vantagem de mostrar a situação em Ogígia como resultado do caso dos tripulantes com as vacas do Sol, não uma substituição. À parte essa questão, Pedrick tem uma boa definição da Musa como "personagem no nível do discurso" (p. 42). Brandão (2005, p. 42) observa bem que o narrador "deseja demarcar o que lhe cabe, explicitando o seu lugar, o da Musa e o de seu público, bem como ditando à deusa seu programa narrativo", entretanto o $\alpha \mu$ ó $\theta \varepsilon v$ (a partir de qualquer ponto) só pode ser um recurso retórico para se referir à multiplicidade de pontos de partidas possíveis, como ele propõe, se for considerado que há esse limite inicial estabelecido. Algo como "comece de qualquer ponto, desde que Odisseu esteja sozinho".

${ }^{17}$ Quem faz uma leitura mais detalhada das relações de tempo na narrativa da Odisseia é Delebecque (1980).
} 
Os tripulantes são mencionados pela primeira vez no verso 5, enquanto a Odisseia se coloca como poema de vóotos, de retorno de guerreiros gregos após a guerra de Troia, ${ }^{18}$ (versos 2 e 5) e explicita Odisseu como o herói do sofrimento (verso 2 e 4) e da aventura (verso 3). A primeira informação que recebemos sobre os companheiros é que o sofrimento do herói não foi só para salvar a própria vida: foi também para garantir o retorno deles. A segunda informação é que a tentativa de salválos não deu certo (I, 5-6). O verso 7, que traz a justificativa para o fracasso do retorno deles, é o mais importante na apresentação dos tripulantes e traz três informações: os tripulantes morreram, morreram por insensatez, insensatez cometida por eles mesmos.

As três informações os colocam como opostos de Odisseu, que pode não ter ainda completado seu retorno, mas está vivo e foi caracterizado pela experiência e capacidade mental. Essa oposição é explicitada no verso 8, em que os tripulantes são caracterizados como infantis ( $v \eta ́ \pi \iota \mathrm{o})$, na primeira posição do verso, a mesma da primeira caracterização de Odisseu como

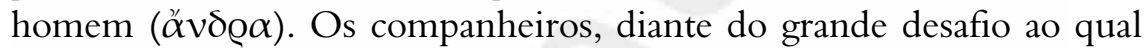
acabam sujeitos, portam-se como inexperientes e pouco espertos.

No primeiro momento, os companheiros aparecem apenas como objetos da preocupação de Odisseu. Quando se tornam agentes, a ação é a catástrofe. O detalhe de que eles mesmos são responsáveis pela realização da insensatez isenta aqui Odisseu da culpa por suas mortes. ${ }^{19}$ A questão de haver algum nível de independência na ação desastrosa em relação a fatores externos ao agente aparecerá pouco depois na fala de Zeus a respeito da relação entre deuses e homens. A palavra-chave aqui é $\alpha \tau \alpha \sigma \theta \alpha \lambda i ́ \alpha$, que descreve principalmente o comportamento da tripulação e dos pretendentes na Odisseia.

Finkelberg propõe três padrões para pensar o erro humano

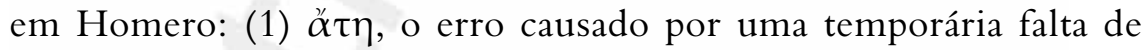
entendimento, uma ação irracional que os personagens tentam explicar como efeito de uma ação externa, divina; (2) $\alpha \dot{\tau} \alpha \sigma \theta \alpha \lambda$ í $\alpha$, o erro que é fruto do mau julgamento de uma ação planejada e deliberada, quando

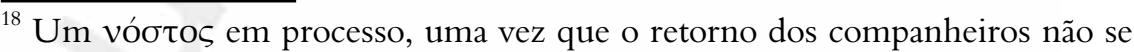
realiza e o de Odisseu começa temporariamente suspenso.

${ }^{19}$ Cf. Clay (1997, p. 34-38) chama atenção para essa defesa de Odisseu e a proposta de apresentá-lo inicialmente de forma moralmente positiva. Friedrich (1987, p. 394-395) propõe o sentido adicional de apresentar os humanos como "arquitetos de sua própria ruína”. Nagler (1990) também indica que o proêmio introduz a questão da culpabilidade no poema.
} 
o agente é avisado com antecedência sobre a possibilidade de desgraça em decorrência do que planeja fazer $;^{20}$ (3) o erro causado pela falta de autocontrole, a incapacidade de conter o $\theta v \mu o ́ s$, sede das emoções. ${ }^{21}$ Das

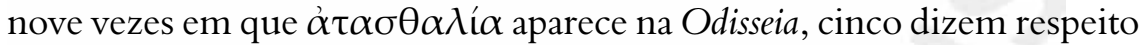
aos pretendentes (XXI, 146; XII, 317; XII, 416; XIII, 67; XXIV, 458), duas à tripulação (I, 7 e XII, 300), uma a Egisto (I, 34, outro modelo negativo de comportamento, um paralelo para os pretendentes) e uma a Odisseu (X, 437).

O caso que se refere a Odisseu é uma fala de Euríloco, o membro da tripulação que se coloca como liderança rival à do herói e o acusa de ter cometido a insensatez de conduzir os companheiros à caverna do ciclope e assim ser responsável pela morte deles. A fala de Euríloco é sinal da oposição que surge entre o capitão e sua tripulação e não é um discurso sem embasamento. Ao narrar essa aventura, o próprio herói admite que os tripulantes tentaram convencê-lo a ir embora antes que o monstro aparecesse. Isso poderia ter poupado a vida de alguns tripulantes devorados por Polifemo e, posteriormente, teria evitado a fúria de Posseidon decorrente da prece de seu protegido. Odisseu insiste porque, ainda inexperiente sobre o mundo em que navegava, queria ser recebido como hóspede (IX, 224-229). O herói que aporta na ilha do ciclope ainda não tem a experiência apresentada no início da Odisseia. A viagem, que amplifica todas as possibilidades do inesperado que o mundo pode oferecer, faz dele um homem cauteloso, que cogita e teme o indeterminado ao entrar em zonas desconhecidas (V, 229; V, 465; VI, 119). A acusação de

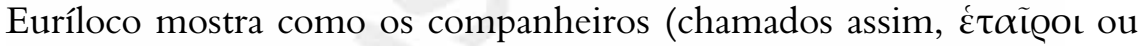

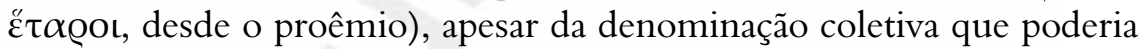
sugerir a proximidade e camaradagem de quem está no mesmo barco, não se contrapõem a Odisseu apenas para compor a apresentação inicial dos personagens no proêmio. ${ }^{22}$ Os tripulantes põem o retorno em risco entre

${ }^{20}$ Cf. Finkelberg (1995, p. 18), para quem o termo é moralmente neutro, podendo ser qualificado por űß@ı, , a arrogância imoral para um humano, mas não simplesmente substituído por ele. Também Fuqua (1991), apesar de não ser muito preciso ao considerar a $\alpha \tau \alpha \sigma \theta \alpha \lambda$ í $\alpha$, concorda que em Homero não há um sentido moral por si só. Para Finkelberg, a Ilíada é o poema que enfatiza a ő̃ a Odisseia, a $\dot{\alpha} \tau \alpha \sigma \theta \alpha \lambda i ́ \alpha$.

${ }^{21}$ Cf. Finkelberg (1995, p. 16-25). Na Odisseia, essa incapacidade de conter o $\theta v \mu o ́ s$ talvez apareça mais como algo que leva à $\alpha \tau \alpha \sigma \theta \alpha \lambda i ́ \alpha$, ou ao menos como tipo de reação que pode surgir junto com ela.

${ }^{22}$ Louden (1999) interpreta a Odisseia propondo uma estrutura narrativa em 
os cícones, entre os lotófagos, após a ajuda de Éolo, quando chegam à ilha de Circe, e finalmente conseguem se arruinar completamente na Trinácia. Odisseu os põe em risco na ilha do ciclope, se atrasa sem previsão de partida na ilha de Circe e precisa sacrificar alguns companheiros na travessia de Cila e Caríbdis. ${ }^{23}$ Talvez seja impossível viajar em companhia de outros sem conflitos, mas alguns erros têm consequências mais decisivas.

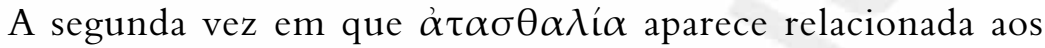
tripulantes é numa fala de Odisseu a Euríloco (XII, 300). Aqui, sim, Odisseu, como apresentado no proêmio e com informações privilegiadas antecipadas por Tirésias e Circe (IX, 104 e XI, 127-141), tenta assegurar a salvação de seus tripulantes, pedindo que jurem não cometer a insensatez de matar o gado do Sol. ${ }^{24}$ Odisseu recorda e avisa aos companheiros (XII, 271-276) que o adivinho e Circe anunciaram com antecipação que era melhor evitar a ilha, porque lá se encontrava o pior perigo de todos, porém o modo como o herói narra o episódio faz transparecer algum sentimento de culpa. Conforme sua própria narração, nesse episódio ele não repassa aos companheiros algo essencial do oráculo: as três opções de conduta (apresentadas por Tirésias em XI, 104-114 e por Circe em XII, 137-141) da profecia que se apresentam como possibilidades: ${ }^{25}$ a) se refrear o coração

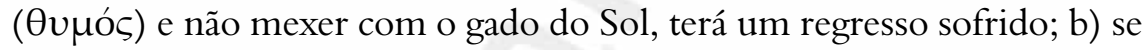
fizer mal ao gado, receberá desgraça; c) se apenas Odisseu evitar fazer mal ao gado, regressará depois de um longo tempo e sem os companheiros. O narrador, por sua vez, desculpa Odisseu desde o proêmio e mesmo o herói não omite de sua narrativa o juramento que exigiu dos companheiros. Também desde o proêmio o receptor já sabe que o juramento não será

três partes, cada uma com um grupo opositor: a tripulação, os atletas feaces e os pretendentes (liderados por Euríloco, Euríalo e Eurímaco).

${ }^{23}$ Segal (1994, p. 34-35) lista com mais precisão os momentos em que transparece a dificuldade de Odisseu em comandar seus homens: da recusa da tripulação de logo deixar os cícones (IX, 44) até Euríloco o forçar a aportar na ilha de Trinácia, onde estão as vacas do Sol (XII, 278).

${ }^{24}$ Quanto à disposição de Odisseu para salvar seus companheiros, Reinhardt (1995) observa no episódio de Circe como Odisseu corajosamente arrisca sua vida, uma vez que, ao partir para averiguar a situação dos tripulantes, ele não poderia imaginar que receberia ajuda de Hermes.

${ }^{25}$ Cf. Marks (2008, p. 95), que vê na profecia de Tirésias a indicação de alguns possíveis futuros não-homéricos de Odisseu, e Peradotto (1990, p. 66-67), que indica a natureza condicional da profecia que explicita a moldura em que a decisão acontecerá. 
cumprido e que a causa da morte e da falha dos companheiros em retornar para casa será o fato de devorarem o gado do deus e provocarem sua fúria. É importante notar que a tripulação consome a carne proibida da propriedade de um deus, assim como os pretendentes consomem a carne proibida da propriedade de outro homem. ${ }^{26}$ Ambos os grupos cometem uma transgressão e serão duramente punidos com a morte. ${ }^{27}$

A oposição a Odisseu, a $\alpha \tau \alpha \sigma \theta \alpha \lambda$ í $\alpha$, o consumo de carne interdita, a punição e mesmo o desprezo por avisos aproximam tripulantes e pretendentes, mas não convém ignorar as diferenças das circunstâncias em que suas transgressões acontecem. A principal distinção é que os pretendentes, diante da situação atípica de um homem que nem retorna para casa, nem é confirmado como morto, criam para si mesmos o cenário - o assédio a Penélope e à casa de Odisseu - que os leva aos atos de insensatez, enquanto os tripulantes respondem (de forma insensata) a uma situação de risco à qual foram levados por forças além de seu controle.

O proêmio explicita a relação entre deuses e homens em dois momentos. No primeiro verso do poema, o narrador se coloca como dependente da Musa para desenvolver sua narrativa, ${ }^{28}$ que tem ainda o "homem" como objeto. Nos versos 9 e 10, a fúria do Sol revela que os homens são submetidos ao temperamento de deuses pela violação de suas prerrogativas e que a $\alpha \dot{\tau} \alpha \sigma \theta \alpha \lambda$ í $\alpha$, apesar de não ter por si só um significado moral, aparece em momentos importantes da Odisseia relacionada ao pensamento sobre a ação humana e a ação divina, pela má decisão de ofender e de ignorar as indicações dadas por um deus.

$\overline{{ }^{26} \text { Observa Nagler }}(1990$, p. 339-340) que a tripulação ao menos tenta uma simulação do ritual de sacrifício (XII, 356-363, com preces, mas sem grãos e vinho), enquanto os pretendentes parecem o ignorar (exceto Anfínomo, cf. Detienne, 1998, p. 47). A carne constrói um paralelo entre os dois grupos também como imagem sobrenatural. Para os tripulantes, o couro do gado rasteja e a carne no espeto muge (XII, 394-396). Para os pretendentes, a carne que comem está ensopada de sangue, enquanto eles riem e choram (XX, 345-349).

${ }^{27}$ Para Nagler (1990, p. 341), o assassinato sacrílego do gado do Sol é um comentário ao desprezo dos tripulantes pelas leis sociais e econômicas, que estabelece a lógica sacrificial que se aplicará aos pretendentes e justifica o massacre, "a violência do herói contra seu grupo social apresentada como único meio de recuperar ou estabelecer ordem".

${ }^{28}$ E nisso está concentrada a questão da distância entre o limitado conhecimento humano e o conhecimento potencialmente total das divindades e da autoridade do narrador, que, por seu contato com a Musa, é capaz de transmitir informações só acessíveis aos deuses para seus receptores humanos (cf. Clay, 1997, p. 9-25). 
Depois que Odisseu falha em convencer seus companheiros a não desembarcar na ilha do Sol (XII, 278), ventos contrários os obrigam a permanecer na ilha até que seus suprimentos se esgotem. Sem provisões, eles têm que improvisar com a caça de pássaros ou a pesca e inevitavelmente passam fome (XII, 325-332). ${ }^{29}$ Odisseu e os tripulantes se encontram, então, diante de uma decisão: manter uma dieta de fome ou sacrificar o gado do Sol. A decisão equivocada é tomada após um discurso de Euríloco (XII, 340-351):

Ouvi as minhas palavras, vós que tanto sofrestes!

Para os pobres mortais todas as mortes são odiosas, mas morrer à fome é o mais desgraçado dos destinos.

Sacrifiquemos as melhores vacas do Sol aos deuses imortais, que o vasto céu detêm.

Se alguma vez regressarmos a Ítaca, a nossa terra pátria, logo para Hipérion, o Sol, construiremos um templo, e lá deporemos muitas e valiosas oferendas. Mas se o deus contra nós se encolerizar por causa das vacas de chifres direitos e a nau quiser destruir, e se tal consentirem os outros deuses, por mim prefiro morrer de um trago no mar, do que definhar lentamente numa ilha deserta.

Fica claro que a tripulação não sacrifica as vacas por falta de informação. Euríloco trata a questão como se o fluxo de possibilidades fosse o seguinte: (a) em caso de não sacrificar o gado: morte lenta passando fome, (b) em caso de sacrificar o gado: possibilidade de morte por afogamento no mar, (c) em caso de sacrificar e conseguir voltar para casa: necessidade de compensação pela transgressão. ${ }^{30}$ No fim, sua abordagem é em parte excessivamente pessimista e em parte excessivamente otimista. Reduz sua

\footnotetext{
${ }^{29}$ Para Fenik (1974, p. 213) os companheiros são levados a cometer a ação imprópria pelos próprios deuses, que primeiro desencadeiam, com os ventos, uma atitude desesperada nos marinheiros e depois os punem com a morte na tempestade. Rutherford (1986, p. 153) considera a fome da tripulação uma situação sem solução. Entretanto, a ação de Zeus aparece apenas no discurso de Odisseu, não do narrador, e a sobrevivência do herói mostra que haveria saída.

${ }^{30}$ Como observa Finkelberg (1995, p. 26), é uma deliberação o mais racional possível, embora leve à decisão errada. O detalhe é que há uma superposição entre dois dos três tipos de erro que Finkelberg identifica: o erro dos pretendentes é a incapacidade de conter o $\theta v \mu o ́ s$ que leva à $\alpha \dot{\tau} \alpha \sigma \theta \alpha \lambda$ í $\alpha$. A deliberação acontece como resposta à ideia de que não dá para sustentar o desconforto da fome constante.
} 
escolha à inanição ou ao afogamento, mas considera a possibilidade de uma compensação pelo gado que não é a morte. A sobrevivência de Odisseu, a grande façanha de seu autocontrole, é a prova de que a questão real não era escolher o tipo de morte, mas escolher como manter a vida: não resistir a uma alimentação farta e garantida ou suportar um regime sem o bastante para se saciar e sem garantias. ${ }^{31}$ Euríloco e os outros companheiros não são personagens malvados, mas não seguem o aviso repassado por Odisseu porque não têm a resistência e persistência que exigia uma situação de privação que se prolonga indefinidamente e sem perspectiva de solução. Dimock observa isso já no próprio proêmio, condensado na oposição entre $\pi \lambda \alpha \dot{\gamma} \gamma \chi \emptyset \eta$ ("vagou”, ${ }^{32}$ primeira palavra do segundo verso) e ("comeram", primeira palavra do nono verso): enquanto Odisseu aguentou o sofrimento e experienciou o mundo - ou ao menos seguiu viagem através da tempestade —, os tripulantes não resistiram e não sobreviveram. ${ }^{33}$ Ironicamente, no discurso que convence os companheiros a desembarcar

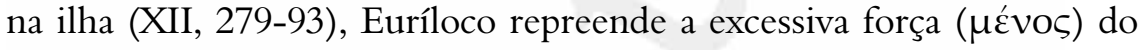
capitão, que o torna duro com sua tripulação cansada, e o incita a aportar para que possam "preparar uma refeição saborosa" e evitar a morte no mar, com as tempestades que sobrevêm repentinas. ${ }^{34}$

O último verso do proêmio o fecha como uma unidade narrativa, com a técnica da composição em anel: retomando a Musa do primeiro verso e a relação do narrador com ela ( $\mu \mathrm{ol}$, "para mim", no primeiro verso

\footnotetext{
${ }^{31}$ Para Friedrich (1987, p. 390-391) a alegação de que só resta escolher entre os dois tipos de morte é um truque retórico de Euríloco, como estratégia de persuasão numa situação em que a autopreservação não está em questão, só a preferência por uma dieta mais farta e mais ao gosto grego. Entretanto, é preciso reconhecer que a vontade de persuadir os companheiros parte de uma situação extrema. Se fosse uma situação segura, o episódio de Trinácia não seria, como Friedrich indica, a

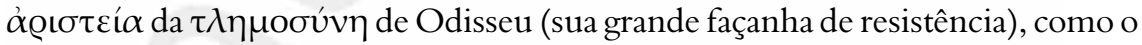
episódio do ciclope é a de sua $\mu \tilde{\eta} \tau \iota \varsigma$ (astúcia), com a ressalva de que, também na caverna de Polifemo, Odisseu precisa conter seu $\theta v \mu$ ó s para não matá-lo com a saída ainda bloqueada (cf. Clay, 1997, p. 123-124). Para Cook (1995, p. 60), como a tripulação é avisada, trata-se de um teste explícito de autocontrole.

${ }^{32}$ Dimock (1989, p. 9-11) chama a atenção para uma ambiguidade entre os sentidos de "vagueou" e "apanhou, foi batido".

${ }^{33}$ Cf. Dimock, 1989, p. 9.

${ }^{34}$ Cf. Louden (1999, p. 15) já observava que no último discurso de Euríloco (XII, 340-351) a pior morte é a fome, mas no discurso que faz com que a tripulação desembarque na ilha (XII, 279-293) é a morte no mar que deve ser evitada a qualquer custo.
} 
e agora ทंนĩv, "para nós", que pode incluir sua audiência, os receptores da narrativa). O pedido para que ela comece a narrativa a partir de qualquer ponto $(\alpha \mu o ́ \theta \varepsilon v)$ é a deixa ${ }^{35}$ para que a narrativa tenha início a partir dos limites já propostos com o caso da morte dos tripulantes. Com o herói e seu poema apresentados, com a exposição de um primeiro modelo contrário a Odisseu, o proêmio termina com uma menção a Zeus, pai das Musas e deus cujos desígnios definem o curso da narrativa. ${ }^{36}$

Os companheiros são o primeiro exemplo de fracasso a partir de uma má leitura do mundo - e de seus sinais e avisos — que os leva à decisão pouco inteligente de cometer uma impiedade. São também o primeiro exemplo das consequências extremas da fúria de um deus movido por interesses particulares. $\mathrm{Na}$ segunda parte de seu retorno, Odisseu usará das mesmas qualidades que lhe permitem iniciar a narrativa como único sobrevivente para retomar Ítaca. Terá, porém, o interesse particular de um deus a seu favor.

\section{Referências}

BASSETT, S. E. The Proems of the "Iliad" and the "Odyssey". The American Journal of Philology, Baltimore, vol. 44, n. 4, p. 339-348, 1923.

BRANDÃO, J. L. Antiga musa: (arqueologia da fiçãa). Belo Horizonte: Faculdade de Letras da UFMG, 2005.

CLAY, J. S. The wrath of Athena. New York: Rowman \& Littlefield Publishers, 1997.

COOK, E. The "Odyssey" in Athens: myths of cultural origins. London and Ithaka: Cornell University Press, 1995.

DE JONG, I. J. F. A narratological commentary on the "Odyssey". Cambridge: Cambridge University Press, 2001.

DELEBECQUE, É. Construction de l' "Odyssée”. Paris: Les Belles Lettres, 1980.

DETIENNE, M. Une fête pure, et du sang sur la table. In: DETIENNE, M. Apollon le couteau à la main: une approche expérimentale du polythéisme grec. Paris: Gallimard, 1998, p. 41-61.

DIMOCK, G. E. The name of Odysseus. The Hudson Review, New York, vol. 9 , n. 1, p. 52-70, 1956.

DIMOCK, G. E. The unity of the "Odyssey". Amherst: The University of Massachusetts Press, 1989.

\footnotetext{
${ }^{35} \mathrm{Ou}$ "estratagema retórico" (de Jong, 2001, p. 7).

${ }^{36}$ Sobre a narrativa da Odisseia como realização do plano de Zeus e definição da narrativa pan-helênica entre as narrativas regionais, cf. Marks, 2008.
} 
FENIK, B. Studies in the Odyssey: Hermes Einzelschriften 30. Wiesbaden: F. Steiner, 1974. FINKELBERG, M. Patterns of Human Error in Homer. The Journal of Hellenic Studies, London, vol. 115, p. 15-28, 1995.

FRIEDRICH, R. Thrinakia and Zeus's ways to men in the "Odyssey". Greek, Roman and Byzantine Studies, Durham, vol. 28, p. 375-400, 1987.

FUQUA, C. Proper Behavior in the Odyssey. Illinois Classical Studies, Champaign, vol. 16, n. 1/ 2, p. 49-58, 1991.

GOLDHILL, S. The poet's voice: essays on poetics and Greek literature. New York: Cambridge University Press, 1991.

HEUBECK, A.; WEST, S.; HAINSWORTH, J. B. A commentary on Homer's "Odyssey" vol. I, Books i-viii. Oxford: Oxford University Press, 1988.

HOMERO. Odisseia. Trad. e prefácio de Frederico Lourenço, introd. e notas de Bernard Knox. São Paulo: Penguin Classics/Companhia das Letras, 2011.

HOMERO. Odisseia. Trad., posfácio e notas de Trajano Vieira, ensaio de Italo Calvino. São Paulo: Editora 34, 2012.

KAHANE, A. The first word of the "Odyssey". Transactions of the American Philological Association, Baltimore, vol. 122, p. 115-131, 1992.

LOUDEN, B. The "Odyssey": structure, narration and meaning. Baltimore: The Johns Hopkins University Press, 1999.

MALTA, A. Polú pollá pollôn: multiplicidade no proêmio da "Odisseia". Synthesis, La Plata, vol. 14, p. 53-70, 2007.

MARKS, J. Zeus in the "Odyssey". Cambridge: Harvard University Press, 2008.

NAGLER, M. N. Odysseus: the proem and the problem. Classical Antiquity, Berkeley, vol. 9, n. 2, p. 335-356, 1990.

PEDRICK, V. The muse corrects: the opening of the "Odyssey". In: DUNN, F. M.; T. COLE (org.). Beginnings in Classical Literature. Cambridge: Cambridge University Press, 1992, p. 39-62.

PERADOTTO, J. Man in the middle voice: name and narration in the "Odyssey". Princeton: Princeton University Press, 1990.

PUCCI, P. The proem of the "Odyssey”. The Song of the Sirens. Lanham: Rowman \& Littlefield Publishers, 1998, p. 11-29.

RACE, W. H. First appearances in the "Odyssey". Transactions of the American Philological Association, Baltimore, vol. 123, p. 79-107, 1993.

REINHARDT, K. The adventures in the "Odyssey". In: SCHEIN, S. L. (org.). Reading the "Odyssey": selected interpretive essays. Edited with an introduction by Seth L. Schein. Princeton: Princeton University Press, 1995, p. 63-132.

RIJKSBARON, A. Why is the incident on Thrinacia mentioned in "Od." 1, 7-9? Mnemosyne, Amsterdam, vol. 46, fasc. 4, p. 528-529, 1993.

RUTHERFORD, R. B. The philosophy of the "Odissey". The Journal of Hellenic Studies, London, vol. 106, 1986, p. 145-162. 
SEGAL, C. Singers, heroes, and gods in the "Odyssey". Ithaka: Cornell University Press, 1994.

STEINRÜCK, M. The suitors in the "Odyssey": the clash between Homer and Archilochus. New York: Peter Lang Publishing, 2008.

VAN GRONINGEN, B. A. The proems of the Iliad and the Odyssey. In: DE JONG, I. J. F. (org.) Homer: Critical Assessments, vol. 3: Literary Interpretation. London: Routledge, 1999, p. 109-118.

WALSH, T. R. "Odyssey" 1.6-9: a little more than kine. Mnemosyne, Amsterdam, vol. 48, fasc. 4, 1995. p. 385-410. 